\title{
SPATIAL VARIATION OF SOIL MOISTURE CONTENT OF A STEPPED SLOPE UNDER SPRINKLER IRRIGATION AND ITS AFFECTING FACTORS
}

\author{
SUN, H. Y. ${ }^{1 \#}-$ LIU, L. ${ }^{1,2 \# *}$ \\ ${ }^{I}$ Northwest Institute of Eco-Environment and Resources, Chinese Academy of Sciences, \\ Lanzhou, Gansu Province730000, China \\ ${ }^{2}$ University of Chinese Academy of Sciences, Beijing 100049, China \\ ${ }^{\#}$ These authors contributed equally to this work. \\ *Corresponding author \\ e-mail:liule@lzb.ac.cn
}

(Received $27^{\text {th }}$ Sep 2019; accepted $4^{\text {th }}$ Feb 2020)

\begin{abstract}
In this study, the soil moisture migration pattern was studied under the sprinkler irrigation method with different modes of a stepped slope with 3 steps and its affecting factors. The results showed that at the early stage of the vegetation reconstruction, natural precipitation was enough to ensure the normal growth. This was found valid as long as the soil moisture content (SMC) was higher than $2.45 \%$ of the wilting coefficient at the non-irrigation stage. At the non-irrigation stage and at the stage of irrigation once every two days, the SMC increased with depth in the three slope surfaces. However, at the stage of irrigation once daily, the SMC decreased with depth. As the irrigation frequency decreased, the SMC dropped and the coefficient of variation (CV) of SMC rose. The order of CV of SMC within depths in 0-50 cm soil layer was the depths of $40-50 \mathrm{~cm}>0-2 \mathrm{~cm}$ and $0-20 \mathrm{~cm}>20-40 \mathrm{~cm}$. The average soil moisture content (ASMC) increased from the top to the bottom of the stepped slope under different frequencies of sprinkler irrigation. The slope position and hardness and vegetation cover correlated negatively with the SMC $(\mathrm{P}<0.01)$. Whereas, the slope gradient correlated positively with the SMC $(\mathrm{P}<0.05)$.
\end{abstract}

Keywords: Lanzhou New Area, Loess Plateau, ecological restoration, vegetation reconstruction, spatial differentiation, environmental factor

\section{Introduction}

Excavation and filling of large mountains in Lanzhou New Area, located in the Loess Plateau of the Peoples Republic of China have produced a very high number of exposed stepped slopes during infrastructure construction. This has greatly changed the original ecological environment and led to water and soil loss (Cohen-Fernández and Naeth, 2013; Sharma et al., 2017). The total area suffering this loss was about $40 \mathrm{hm}^{2}$. Each exposed stepped slope usually consists of three steps and every two adjacent steps are isolated by a terrace. For these steep slope surfaces, vegetation slope protection is an effective pathway towards ecological restoration (Stokes et al., 2008). For this, the primary technical measures are available for sustainable development of the Loess Plateau (Wu and Yang, 1998). Soil moisture is a key factor affecting vegetation growth in the Loess Plateau (Engelbrecht et al., 2007; Wu and Yang, 1998). Small-scale topographical changes control secondary distribution of light, heat, precipitation and surface runoff (Crave and Gascuel-Odoux, 2015). All these, further affect the variability of soil moisture content (SMC) across the space. The spatial variation of SMC thus resulted, has a decisive impact on the surface vegetation type, density and structure (Vivoni et al., 2010). Steep slopes are usually associated with severe soil moisture shortage due to low permeability and high surface 
runoff (Miyazaki et al., 1993). The phenomenon is distinct especially for the slopes with greater hardness (Morgan, 1980). Hardness occurs because the slopes are formed via engineering construction. The process causes a compaction of particles which decreases the porosity and increases the bulk weight (Soane et al., 1980). The resultant condition hinders the circulation of moisture and nutrients, which is not conducive to the root growth of vegetation (Ishaq et al., 2001). Previous studies mostly dealt with the spatial variation of SMC in the gentle natural slopes of the Loess Plateau (Jia et al., 2013; Yang et al., 2015) and in typical roadbed side slopes (Yang et al., 2016). However, we know little about the spatial variation of SMC in stepped slopes. In this study, vegetation reconstruction was carried out for the steep slopes in Lanzhou New Area by sprinkler irrigation and mechanized grass growing. Then, a correlation analysis was conducted between the spatial variations of features of SMC in the $0-50 \mathrm{~cm}$ soil layer. In the correlation studies, different irrigation frequencies and four environmental factors namely, soil hardness, slope position and gradient and vegetation cover were considered. The soil moisture response to slope gradient and soil hardness in vegetation reconstruction of stepped slope was discussed. The present study provides a theoretical basis for developing irrigation regime and engineering measures for vegetation restoration in similar stepped slopes.

\section{Study sites}

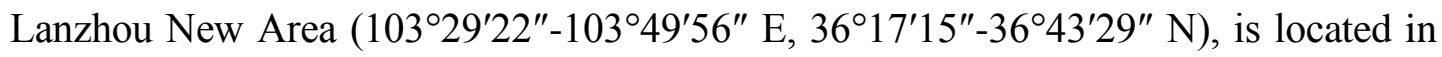
Qinwangchuan Basin of the Peopole's Republic of China. The study area is about $60 \mathrm{~km}$ away from the city of Lanzhou (Fig. 1). The area is located in the intersect of QinghaiTibet-, Mongolian- and Loess Plateau. In that the eastward extending ranges of the Qilian Mountain run into the interlaced region of Longxi Basin. The primary landform of Lanzhou New Area is the Loess Plateau. The area enjoys typical temperate, continental and semiarid climate with an annual average temperature of $6.9^{\circ} \mathrm{C}$ and annual precipitation of $300-350 \mathrm{~mm}$. Because of the slope factor, the vegetation of the Loess Plateau near Lanzhou New Area shows two different categories i.e., shady and sunny slopes. The shady slope is predominantly grown with Stipa breviflora Desf. accompanied by undershrubs and perennial herbs such as Caragana tibetica (Maxim. ex C.K. Schneid.) Kom., C. opulens Kom., Krascheninnikovia ceratoides (L.) Gueldenst., Ajania achilleoides (Turcz.) Poljakov ex Grubov, Torularia humilis (C.E. Mey) O.E. Schulz, Peganum harmala L., Limonium aureum (L.) Hill and Reaumurta soongorica (Pall.) Maxim. Whereas, the sunny slope is mainly grown with desert shrub $R$. soongorica accompanied by annual plants such as Salsola collina Pall., Suaeda glauca (Bunge) Bunge and Setaria viridis (L.) P. Beauv. The above undisturbed soil vegetation is an important indicator for vegetation reconstruction of steep slopes in Lanzhou New Area.

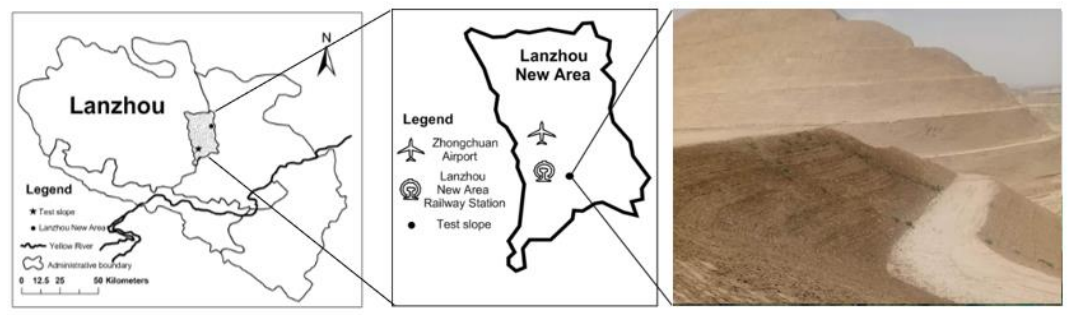

Figure 1. Location map of study area 


\section{Methods}

\section{Time and location of the experiments}

Experiments for the present study were performed from June $2^{\text {nd }}$ to October $23^{\text {rd }}$, 2018. The experimental slopes $\left(103^{\circ} 44^{\prime} 11^{\prime \prime} \mathrm{E}, 36^{\circ} 27^{\prime} 41^{\prime \prime} \mathrm{N}\right)$ was located on the west side of Nanraocheng Highway (from Shuiqin Road Overpass to Jingshiqi Road) (Fig. 1). The slopes were faced eastward and followed three successive steps having an elevation of $1930 \mathrm{~m}$ MSL. The slope surface was smooth, the soil characteristic had been analysed and the results showed that the soil was barren (Table 1) and without undisturbed soil vegetation. The wilting coefficient of the slope was $6.20 \pm 0.60 \%$.

Table 1. Soil nutrient characteristics in the study area

\begin{tabular}{c|c|c|c|c|c|c}
\hline $\begin{array}{c}\text { Organic } \\
\text { matters } \\
(\mathbf{g} / \mathbf{k g})\end{array}$ & $\begin{array}{c}\text { Total } \\
\text { nitrogen } \\
(\mathbf{g} / \mathbf{k g})\end{array}$ & $\begin{array}{c}\text { Total carbon } \\
(\mathbf{g} / \mathbf{k g})\end{array}$ & $\begin{array}{c}\text { Total } \\
\text { phosphorus } \\
(\mathbf{g} / \mathbf{k g})\end{array}$ & $\begin{array}{c}\text { Alkali- } \\
\text { hydrolyzable } \\
\text { nitrogen } \\
(\mathbf{m g} / \mathbf{k g})\end{array}$ & $\begin{array}{c}\text { Rapidly } \\
\text { available } \\
\text { phosphorus } \\
(\mathbf{m g} / \mathbf{k g})\end{array}$ & $\begin{array}{c}\text { Rapidly } \\
\text { available } \\
\text { potassium } \\
(\mathbf{m g} / \mathbf{k g})\end{array}$ \\
\hline 1.742 & 0.268 & 15.405 & 1.28 & 10.50 & 11.46 & 120.00 \\
\hline
\end{tabular}

\section{Experimental layout}

\section{Slope engineering and grass growing}

One study in 2017 indicated that a definite strip soil preparation (average length $\times$ width $\times$ depth $=45 \times 8 \times 5 \mathrm{~cm}$ ) brought about the best water-retaining and vegetation restoration effects (Liu et al., 2019). Thus in 2018, after manually removing the rubbles and garbage from the slope, the experimental slope was prepared. To produce strip-like trenches with a depth of about $7 \mathrm{~cm}$, a three-teethed harrow was used. The trenches were parallel with each other and spaced about $15 \mathrm{~cm}$ apart. From June $2^{\text {nd }}$ to $6^{\text {th }}, 2018$ mechanized grass growing was carried out using sand-fixing mixture. Spray seeding was performed for the test slopes. The seeds of Caragana korshinskii Kom. $\left(6 \mathrm{~g} / \mathrm{m}^{2}\right)$, Agropyron cristatum (L.) Gaertn. $\left(12 \mathrm{~g} / \mathrm{m}^{2}\right)$ and Medicago sativa L. $\left(2 \mathrm{~g} / \mathrm{m}^{2}\right)$ were sown. After spray seeding, the test slope was covered with non-woven fabrics, which were fixed with disposable chopsticks. The date of first germination was June $11^{\text {th }}, 2018$ and the non-woven fabrics were removed after germination.

\section{Sample plot layout}

The bottom slope surface in the stepped slope (Fig. 2a) was considered the first $\left(1^{\text {st }}\right)$ one. It had a length of $12 \mathrm{~m}$ in the upper and lower direction and the slope gradient was $60^{\circ}$. The middle slope surface was considered the second $\left(2^{\text {nd }}\right)$ one which had a length of $14 \mathrm{~m}$. In this case, the slope gradient was $40^{\circ}$. Between the first and second slope surfaces, there was a $3 \mathrm{~m}$-wide terrace. The top slope surface was considered the third $\left(3^{\text {rd }}\right)$, with a length of $12 \mathrm{~m}$. Here the slope gradient was $25^{\circ}$. There was a $12 \mathrm{~m}$ wide terrace between the second and third slope surfaces.

A $1 \times 1 \mathrm{~m}$ sample plot was arranged at the upper (P), middle (M) and lower (D) positions of the first, second and third slope surfaces, respectively and each with three replicates. Thick iron wires and hemp ropes were used for immobilization (Fig. 2b). Nine plots were arranged for each slope surface. So, the entire test slope had 27 plots. The plot in the upper position of each slope surface was $1 \mathrm{~m}$ away from the top of this slope 
surface. The lower position was $1 \mathrm{~m}$ away from the bottom of the slope surface. The transverse spacing between adjacent plots was $10 \mathrm{~m}$ and the vertical spacing was 3-4 m.

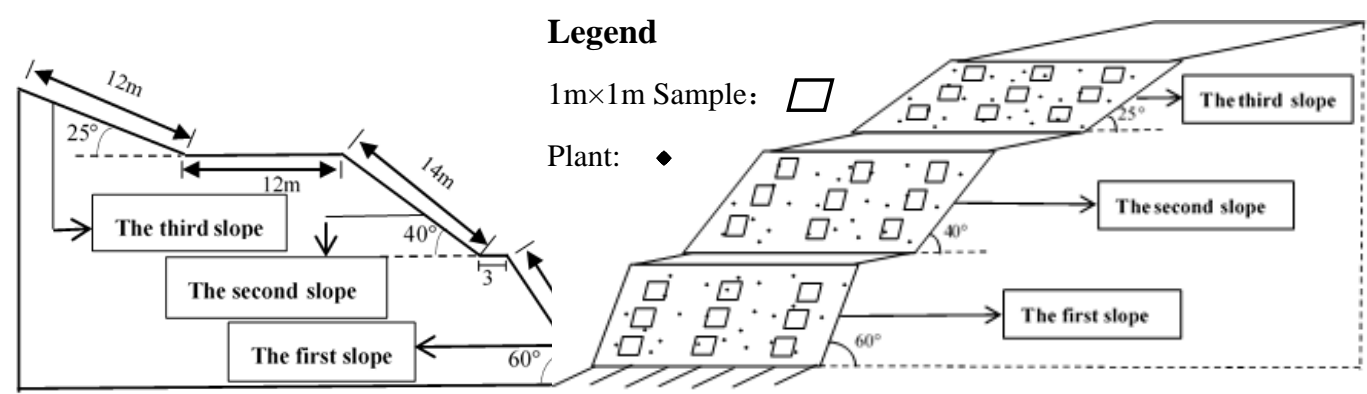

$\mathbf{a}$

b

Figure 2. The schematic diagram of profile and sample layout for the test slope. a Schematic for the s profile of the test slope. $\boldsymbol{b}$ Schematic for the sample plot layout of the test slope

\section{Sprinkler irrigation method and its application frequency}

Sprinkler irrigation was performed for the experimental slopes. That is, all the three slope surfaces were irrigated by a sprinkling truck at 7-8 a.m. every day. The sprinkler irrigation amount was the same for different slope surfaces and the total sprinkler irrigation amount of the three slope surfaces was $12 \mathrm{MT} / \mathrm{day}$. The frequency of irrigation followed three-time intervals. These are: (i) from June $2^{\text {nd }}$ to July $10^{\text {th }}$ sprinkler irrigation once daily; (ii) from July $11^{\text {th }}$ to August $15^{\text {th }}$ sprinkler irrigation once at every two days interval and (iii) from August $15^{\text {th }}$ to November $23^{\text {rd }}$ no irrigation, but natural precipitation was the only source of water. Sprinkler irrigation was avoided on the day of precipitation for all the experimental plots.

\section{Sample collection, data collection and processing}

\section{Method of sample collection for SMC determination}

At the irrigation stage, each plot was sampled once every $2 \mathrm{~h}$ since $9 \mathrm{a} . \mathrm{m}$. on the morning of sprinkler irrigation. However, at the non-irrigation stage (natural precipitation), each plot was sampled at 9 a.m. once every $10 \mathrm{~d}$.

A soil auger was used to collect samples for SMC determination. The sampling was carried out at randomly chosen positions for the soil depth of $0-50 \mathrm{~cm}$ under different irrigation frequencies. The soil was divided into 6 layers, namely, topsoil at $0-2 \mathrm{~cm}, 2-$ $10 \mathrm{~cm}, 10-20 \mathrm{~cm}, 20-30 \mathrm{~cm}, 30-40 \mathrm{~cm}$ and $40-50 \mathrm{~cm}$. The collected soil samples were put into specialized high-density ziplock bags prior to determination. The sampled soil pits were backfilled.

\section{Determination of SMC}

SF - 60 Moisture Tester (Shenzhen Houwang Electronic Technology Co., Ltd.) was used to determine the SMC. The measuring range was $0.01-100 \%$ and the measuring precision was $0.01 \%$. During the first determination, the tester was calibrated by using the oven drying method (error 0.5-1\%). For subsequent determinations, the SMCs were all detected using the electronic soil moisture tester. Each detection was repeated for three times and the average was taken. 


\section{Determination of soil hardness}

Soil hardness tester (Takemura Electric Works, Ltd) was placed perpendicular to the soil surface. The top length of the tester was $4.5 \mathrm{~mm}$, and its bottom was inserted deep into the soil. The soil hardness tester was removed perpendicular out of the soil and the readings were taken. The measuring range of the soil hardness tester was $0-500 \mathrm{~kg} \cdot \mathrm{cm}^{-2}$ and the measuring precision was $0.1 \mathrm{~kg} \cdot \mathrm{cm}^{-2}$. A quincunx pattern was chosen for random selection of 5 points in each plot for each determination and average was taken after repeated determinations.

\section{Determination of vegetation cover}

Densities of different plants were calculated for each plot using the quadrat method. Three individuals were randomly selected for each plant species. After collection the crown breadth was measured and the average was taken. The vegetation cover was calculated for each plot based on the projected area of the stems and leaves on the ground.

\section{Division of soil layers based on CV of SMC}

According to the principle of soil layer division based on SMC variability (Yang and Shao, 2000), coefficient of variation (CV) was used to measure the degree of variation of SMC in the vertical direction. CV was calculated by

$$
C V=\frac{S D}{S}
$$

$\mathrm{CV}$ of Equation 1 is the coefficient of variation, $\mathrm{SD}$ is the standard deviation and $\mathrm{S}$ is the average. The smaller the $\mathrm{CV}$, the more stable the SMC was. On the other hand, the larger the CV, the stronger the changes of SMC. Soil layers with CV >30\%, $20 \%<\mathrm{CV} \leq 30 \%, 10 \%<\mathrm{CV} \leq 20 \%$ and $\mathrm{CV} \leq 10 \%$ were considered as rapid changing, active, less active and the relative stable layers, respectively.

\section{Sources of precipitation data in Lanzhou New Area}

Precipitation data of Lanzhou New Area during the test period (Fig. 3) came from the Meteorological Service Center of Gansu Province.

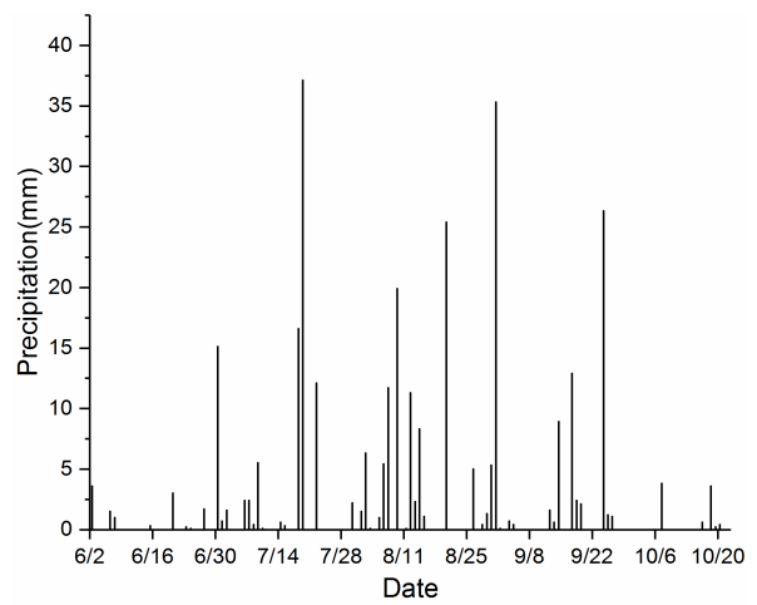

Figure 3. Precipitation in Lanzhou New Area from June $2^{\text {nd }}$ to October $23^{\text {rd }}, 2019$ 


\section{Data analysis}

Statistics was conducted using Microsoft Excel (2013), plots were drawn using Origin (2017) and data analysis was carried out using SPSS (20.0).

\section{Results}

\section{Vertical spatial variation of SMC in the three slope surfaces of stepped slope}

The SMC of each soil layer in different positions of the three slope surfaces have been presented in Fig. 4. At $34 \mathrm{~d}$ under the condition of irrigation once daily, the average soil moisture content (ASMC) ranged between 8.65 and 16.01\% (Fig. 4a). In the $0-50 \mathrm{~cm}$ soil layer, the SMC decreased with increasing depth. At $50 \mathrm{~d}$, under the condition of irrigation once every two days ASMC ranged between 9.81 and $16.28 \%$. The variation trend of SMC in the $0-50 \mathrm{~cm}$ soil layer first increased and then decreased with increasing depth. The SMC, however, reached the highest in the $10-20 \mathrm{~cm}$ soil layer. At $60 \mathrm{~d}$ under the condition of irrigation once every two days, the ASMC ranged between 6.11 and $14.30 \%$. In the $0-50 \mathrm{~cm}$ soil layer, the variation trend in the SMC increased with increasing depth. At 76-144th $d$ and after grass growing, natural precipitation is the only source of recharge to soil moisture in the slope. The ASMC of each soil layer in different positions of the three slope surfaces ranged between 7.47 and $13.39 \%$. Except for the lower position of the third slope surface, the ASMC of the 0$50 \mathrm{~cm}$ soil layer increased with depth. However, ASMC of the $0-50 \mathrm{~cm}$ soil layer in the lower position of the third slope surface remained basically constant with increasing depth. The magnitude of increase or decrease of SMC in each soil layer was below $1 \%$.
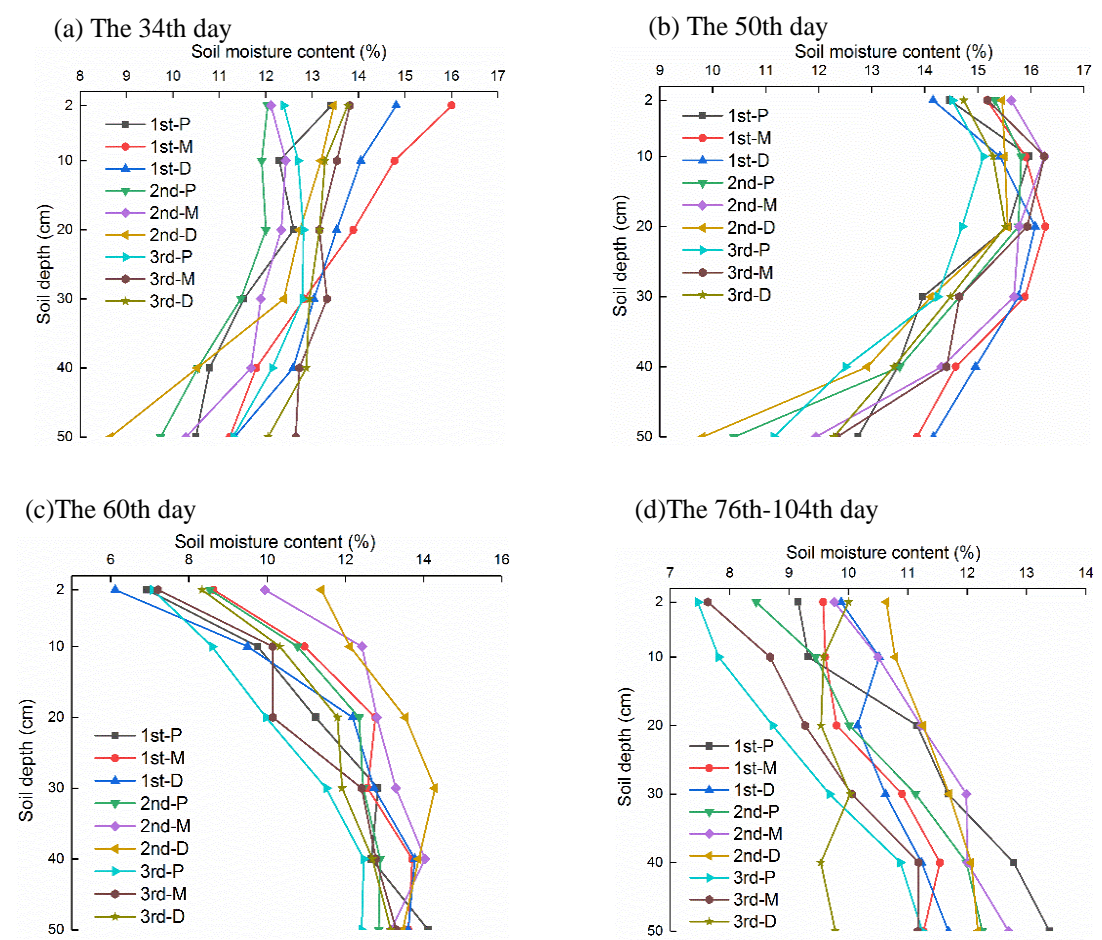

Figure 4. The SMC of three slope positions on the first, second and third slopes in the stepped steep slope under different sprinkling irrigation frequency. (The first, second and third slope surfaces are represented by $1^{\text {st }}, 2^{\text {nd }}, 3^{\text {rd }}$ and the upper, middle and lower slope positions are represented by $P, M$ and $D$ ) 


\section{ASMC under different frequencies of sprinkler irrigation}

Two factor analysis of variance was used to analyze the influence of different frequencies of sprinkler irrigation and slope positions on the variation of ASMC and based on the outcomes of this statistic data could be further processed with least significant difference method (LSD) test. The results showed that there was no significant difference in soil moisture between different slope positions $(\mathrm{P}>0.05)$, different frequencies of sprinkler irrigation has a significant effect on ASMC $(\mathrm{P}<0.05)$. ASMC after strong precipitation was significantly higher than that in other periods $(\mathrm{P}<0.05)$ (Table 2), in addition, ASMC at the non-irrigation stage was significantly higher than that at the stage of sprinkler irrigation once every two days $(\mathrm{P}<0.05)$.

Table 2. LSD test of ASMC under different sprinkler irrigation

\begin{tabular}{c|c|c|c|c}
\hline Frequencies of sprinkler irrigation & The 34th day & The50th day & The 60th day & The 76th-104th day \\
\hline The 34th day & 1 & $-1.977^{*}$ & -0.500 & 0.814 \\
The 50th day & & 1 & $1.477^{*}$ & $2.792^{*}$ \\
The 60th day & & & 1 & $1.314^{*}$ \\
The 76th-104th day & & & & 1 \\
\hline
\end{tabular}

Figure 5 shows the variation of ASMC along 0-50 $\mathrm{cm}$ soil layer, error bars were expressed by standard deviation of ASMC. In addition, dotted lines with integer values close to range of the actual ASMC are added to the figure to make the change trend of ASMC clearer. In the second slope surface, the value was the highest in the lower position, followed by the middle and upper positions successively. However, no consistent variation pattern was found in different positions of the other two slope surfaces. Of the three slope surfaces, at $34 \mathrm{~d}$ (Fig. 5a) the value was the highest in the third slope surface. This was followed by the first and second slope surfaces successively. ASMC of the middle and lower positions of the first slope surface were significantly higher than that of the second slope surface $(\mathrm{P}<0.05)$. However, the differences were not statistically significant as compared with the third slope surface. ASMC of the upper position in the second slope surface was significantly lower than that of the third slope surface $(\mathrm{P}<0.05)$, but the difference was not significant as compared with the first slope surface. Of the three slope surfaces, ASMC at $50 \mathrm{~d}$ (Fig. 5b) was the highest in the first slope surface, followed by the third and second slope surfaces successively. But the value in the middle position of the first slope surface was significantly higher than that of the second slope surface $(\mathrm{P}<0.05)$. However, the differences were not of statistically significant as compared with the third slope surface. ASMC in the upper and lower positions of the other slope surfaces were not significantly different. Of the three slope surfaces, at $60 \mathrm{~d}$ (Fig. 5c) ASMC was the highest in the second slope surface, followed by the first and third slope surfaces successively. In the lower position of the second slope surface, the value was significantly higher than that of the first and third slope surfaces $(\mathrm{P}<0.05)$. However, the differences were not of statistically significant as compared with the upper and middle positions of each slope surface. At 76-104 d (Fig. 5d), the value was the highest in the first slope surface, followed by the second and third slope surfaces successively. In the upper position of the first slope surface it was higher than that of the second and 
third slope surfaces $(\mathrm{P}<0.05)$. However, the differences were not statistically significant as compared with the middle and lower positions of each slope surface.

(a) The 34th

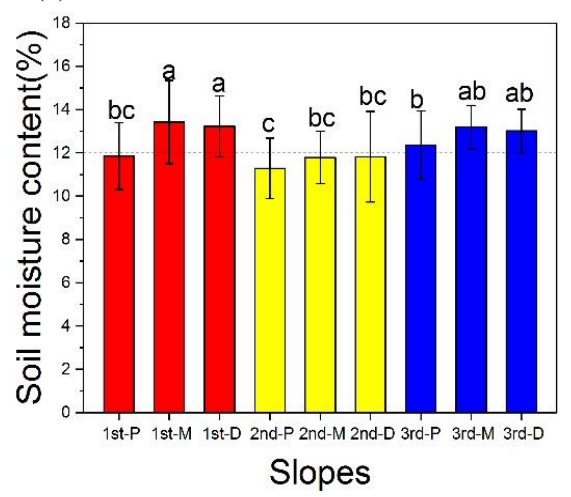

(c)The 60th day

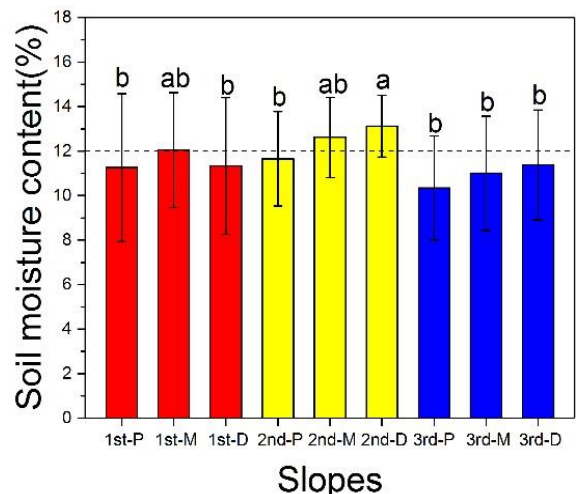

Slopes (b) The 50th day

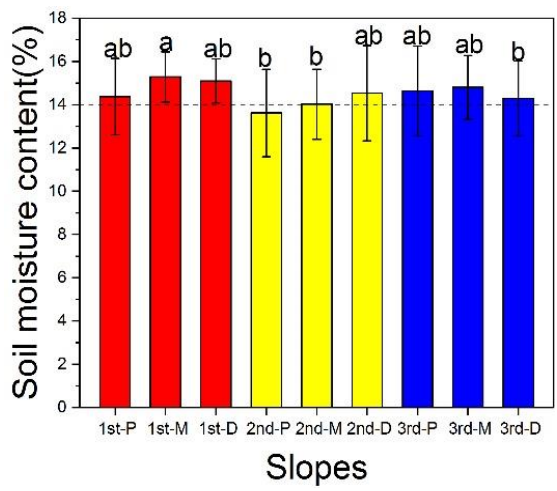

(d)The 76th-104th day

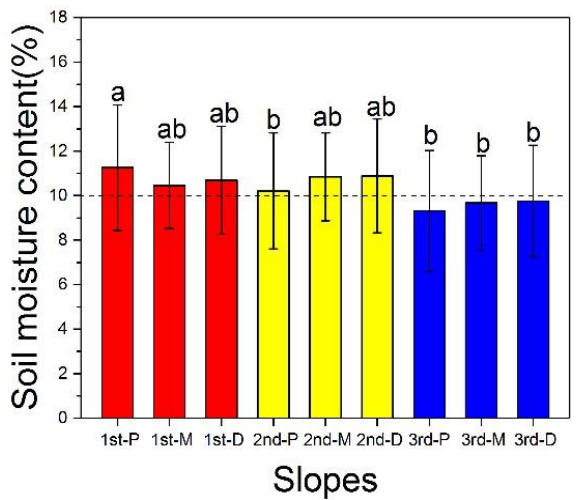

Figure 5. Mean soil moisture content (ASMC) with error bars for different slope positions under different sprinkler irrigation. Different lower-case letters indicate levels of significance $(p<0.05)$ in mean soil water content at different slope positions in the same sprinkler irrigation. (Different lowercase letters are used to indicate significant difference in the ASMC

at different slope positions under the same sprinkler irrigation condition $(P<0.05)$; first, second and third slope surfaces $\left(1^{\text {st }}, 2^{\text {nd }}\right.$ and $\left.3^{\text {rd }}\right)$, upper, middle and lower slope surfaces $(P, M$ and $D)$ )

\section{Stability of SMC of three slope surfaces in the stepped slope}

Soil layers were divided vertically according to the SMC of each slope surface under different irrigation conditions (Table 3). At $34 \mathrm{~d}$, the SMC was basically stable in the three slope surfaces, and CV based on Equation 1 of ASMC was $8.9 \%$. CV was larger in the $0-2 \mathrm{~cm}$ and $40-50 \mathrm{~cm}$ soil layers. These layers were thus considered as the less active layers. CV of other soil layers was all below 10\%, indicating stable SMC. At $50 \mathrm{~d}$, the SMC was generally stable in the three slope surfaces. The CV of ASMC was $6.7 \%$. CV of each soil layer was below 10\%, indicating stable SMC. At $60 \mathrm{~d}$, the three slope surfaces were generally in a less active state and CV of the ASMC was $14.1 \%$. $\mathrm{CV}$ of ASMC was larger in the $0-10 \mathrm{~cm}$ and $40-50 \mathrm{~cm}$ soil layers, corresponding to less active and active state, respectively. The CV was below $10 \%$ in the $10-40 \mathrm{~cm}$ soil layer, indicating stable SMC. At 76-104 d, the three slope surfaces were generally in an active state. In this finding the CV of ASMC was $21.9 \%$. Recording of larger CV in the 0- 
$20 \mathrm{~cm}$ and $40-50 \mathrm{~cm}$ soil layers, indicated an active state. The CV of the $20-40 \mathrm{~cm}$ soil layer showed a value below $20 \%$, so the layer was in a less active state.

Table 3. Vertical variation of SMC on slopes under different sprinkler irrigation conditions

\begin{tabular}{|c|c|c|c|c|c|c|c|c|}
\hline \multirow{2}{*}{ Item } & \multirow{2}{*}{$\begin{array}{l}\text { The slope } \\
\text { positions }\end{array}$} & \multicolumn{7}{|c|}{ Soil depth (cm) } \\
\hline & & $0-2$ & $2-10$ & $10-20$ & $20-30$ & $30-40$ & $40-50$ & Mean \\
\hline \multirow{4}{*}{$\begin{array}{c}\text { The 34th day: } \\
\qquad C V(\%)\end{array}$} & $1 \mathrm{st}$ & 9.0 & 6.3 & 6.3 & 9.0 & 7.7 & 10.7 & 8.2 \\
\hline & 2 nd & 11.7 & 6.7 & 5.3 & 5.7 & 11.3 & 15.7 & 9.4 \\
\hline & $3 \mathrm{rd}$ & 12.7 & 9.3 & 9.0 & 5.3 & 7.3 & 10.7 & 9.1 \\
\hline & Mean & 11.1 & 7.4 & 6.9 & 6.7 & 8.8 & 12.3 & 8.9 \\
\hline \multirow{4}{*}{$\begin{array}{l}\text { The 50th day: } \\
\qquad C V(\%)\end{array}$} & $1 \mathrm{st}$ & 7.7 & 4.0 & 4.7 & 7.0 & 9.3 & 6.3 & 6.5 \\
\hline & $2 \mathrm{nd}$ & 3.7 & 3.0 & 5.3 & 4.7 & 4.7 & 9.3 & 5.1 \\
\hline & $3 r d$ & 8.7 & 5.7 & 8.0 & 9.3 & 10.7 & 9.0 & 8.6 \\
\hline & Mean & 6.7 & 4.2 & 6.0 & 7.0 & 8.2 & 8.2 & 6.7 \\
\hline \multirow{4}{*}{$\begin{array}{l}\text { The 60th day: } \\
\qquad C V(\%)\end{array}$} & $1 \mathrm{st}$ & 25.7 & 15.3 & 14.0 & 10.7 & 11.3 & 31.0 & 18.0 \\
\hline & 2nd & 13.7 & 10.3 & 6.3 & 8.0 & 6.7 & 16.3 & 10.2 \\
\hline & $3 r d$ & 18.7 & 18.3 & 7.7 & 9.7 & 7.0 & 22.7 & 14.0 \\
\hline & Mean & 19.3 & 14.7 & 9.3 & 9.4 & 8.3 & 23.3 & 14.1 \\
\hline \multirow{4}{*}{$\begin{array}{c}\text { The 76th - } \\
\text { 104th day: } C V \\
(\%)\end{array}$} & $1 \mathrm{st}$ & 23.3 & 23.7 & 20.3 & 15.0 & 11.0 & 30.7 & 20.7 \\
\hline & 2nd & 25.3 & 26.3 & 20.0 & 17.7 & 13.3 & 26.7 & 21.6 \\
\hline & $3 \mathrm{rd}$ & 29.0 & 26.7 & 24.0 & 16.7 & 15.3 & 29.0 & 23.4 \\
\hline & Mean & 25.9 & 25.6 & 21.4 & 16.4 & 13.2 & 28.8 & 21.9 \\
\hline
\end{tabular}

\section{Correlation between slope gradient, soil hardness and SMC of the three slope surfaces in the stepped slope}

Of the three slope surfaces (Table 4), the slope gradient was the highest in the first slope surface $\left(60^{\circ}\right)$, followed by the second $\left(40^{\circ}\right)$ and third $\left(25^{\circ}\right)$ slope, successively. As to the average soil hardness, it was the highest in the third slope surface $\left(5.3 \pm 3.68 \mathrm{~kg} \cdot \mathrm{cm}^{-2}\right)$, followed by the second $\left(4.1 \pm 2.78 \mathrm{~kg} \cdot \mathrm{cm}^{-2}\right)$ and first $\left(2.6 \pm 1.24 \mathrm{~kg} \mathrm{~cm}^{-2}\right)$, successively. The ASMC in the $0-50 \mathrm{~cm}$ soil layer during the test period was the highest in the first slope surface $(12.48 \pm 1.80 \%)$, followed by the second $(12.20 \pm 1.44 \%)$ and the third slope $(11.98 \pm 2.19 \%)$, successively.

Table 4. Slope gradient, soil hardness and the average soil moisture content in the 0-50 cm soil layer during the test period of the three slope surfaces in the stepped slope

\begin{tabular}{c|c|c|c}
\hline Slope position & Slope gradient & Soil hardness $\mathbf{( k g \cdot \mathbf { c m } ^ { - 2 } )}$ & Soil moisture content $(\boldsymbol{\%})$ \\
\hline The 1st slope & $60^{\circ}$ & $2.6 \pm 1.24$ & $12.48 \pm 1.80$ \\
The 2nd slope & $40^{\circ}$ & $4.1 \pm 2.78$ & $12.20 \pm 1.44$ \\
The 3rd slope & $25^{\circ}$ & $5.3 \pm 3.68$ & $11.98 \pm 2.19$ \\
\hline
\end{tabular}

Correlation analysis was conducted between SMC of each soil layer within the depth of 0-50 $\mathrm{cm}$ and four environmental factors, namely, slope position and gradient, soil hardness and vegetation cover (Table 5), Pearson correlation coefficient was used to express the magnitude of correlation between soil moisture content and environmental 
factors. The sample size was 90 for SMC determination in each soil layer. The SMC correlated negatively and significantly with the soil hardness $(P<0.01)$. In the $0-50 \mathrm{~cm}$ soil layer, the average correlation coefficient was -0.695 . The correlation coefficient decreased between the SMC and soil hardness with increasing depth. The SMC correlated negatively with the soil hardness. The average correlation coefficient was 0.205 in the $0-50 \mathrm{~cm}$ soil layer. The correlation coefficient between SMC and slope position increased with increasing depth. The SMC in the $40-50 \mathrm{~cm}$ soil layer correlated negatively and significantly with the slope position $(\mathrm{P}<0.05)$. The SMC correlated positively to slope gradient. The average correlation coefficient was 0.179 in the 0 $50 \mathrm{~cm}$ soil layer and it increased with increasing depth. The $\mathrm{SMC}$ in the $40-50 \mathrm{~cm}$ soil layer correlated positively and significantly to slope gradient $(\mathrm{P}<0.05)$. The SMC correlated negatively to vegetation cover. The average coefficient of correlation in the $0-50 \mathrm{~cm}$ soil layer was -0.155 . It first increased and then decreased with increasing depth.

Table 5. Correlation analysis between soil moisture content and environmental factors

\begin{tabular}{c|c|c|c|c}
\hline \multirow{2}{*}{ Soil depth (cm) } & \multicolumn{3}{|c}{ Environmental factors } \\
\cline { 2 - 5 } & Slope positions & Slope gradient & Soil hardness & Vegetation coverage \\
\hline $0-2$ & -0.176 & 0.110 & $-0.625^{* *}$ & -0.154 \\
P value & 0.097 & 0.300 & 0.000 & 0.147 \\
$2-10$ & -0.175 & 0.116 & $-0.625^{* *}$ & -0.197 \\
P value & 0.100 & 0.275 & 0.000 & 0.063 \\
$10-20$ & -0.173 & 0.146 & $-0.607 * *$ & -0.200 \\
P value & 0.103 & 0.169 & 0.000 & 0.059 \\
$20-30$ & -0.162 & 0.147 & $-0.651^{* *}$ & -0.106 \\
P value & 0.126 & 0.168 & 0.000 & 0.322 \\
$30-40$ & -0.176 & 0.206 & $-0.567 * *$ & -0.097 \\
P value & 0.097 & 0.051 & 0.000 & 0.361 \\
$40-50$ & $-0.209 *$ & $0.266^{*}$ & $-0.463 * *$ & 0.042 \\
P value & 0.048 & 0.011 & 0.000 & 0.695 \\
$0-50$ & -0.205 & 0.179 & $-0.695^{* *}$ & -0.155 \\
P value & 0.053 & 0.092 & 0.000 & 0.144 \\
\hline
\end{tabular}

*Significant correlation at the 0.05 level; **significant correlation at the 0.01 level

\section{Discussion}

\section{Vertical migration features of SMC in the stepped slope}

At the stage of sprinkler irrigation once every two days and at the non-irrigation stage, the SMC in the $0-50 \mathrm{~cm}$ soil layer of the stepped slope increased with increasing depth (Fig. 4). The results are in agreement with the findings by Gwak and Kim (2017), Qiang et al. (2013) and Yang et al. (2015). At the stage of sprinkler irrigation once daily, the soil moisture content decreased with increasing depth in the $0-50 \mathrm{~cm}$ soil layer. This finding is just contrary to the variation pattern as described above. Strong precipitation under irrigation once every two days could alter the variation pattern as mentioned above. As a result, the SMC in the $10-20 \mathrm{~cm}$ soil layer was the highest. This is because irrigation once daily was a considerable source of recharge for the slope with 
shorter interval between the irrigations. Strong precipitation usually resulted significant rainwater infiltration and small evaporation and thus provided an efficient recharge to soil moisture in the $0-50 \mathrm{~cm}$ soil layer.

As the frequency of sprinkler irrigation decreased, the soil layer with strong changes in SMC extended from the depth of $0-2$ to $0-10 \mathrm{~cm}$ and finally to $0-20 \mathrm{~cm}$ (Table 5). The SMC in the middle soil layer, i.e., at the depth of $20-40 \mathrm{~cm}$, remained stable. The SMC was stronger at the greater depth of $40-50 \mathrm{~cm}$, which was consistent with the findings by Choi and Jacobs (2007) and Yao et al. (2012). This is because in the semiarid regions, the surface soil moisture is more vulnerable to the influence of precipitation, vegetation transpiration and soil evaporation (Seneviratne et al., 2011). Dense sprinkler irrigation (e.g., once daily) can timely recharge the surface soil moisture. As the frequency of irrigation decreased to once every two days, the surface soil moisture cannot be timely recharged after retention, evaporation and infiltration, leading to significant changes in SMC. In an absence of stable recharge from irrigation at the non-irrigation stage, precipitation served as the only recharge to soil moisture. At this stage, randomness of precipitation made the changes of SMC strongest. The local wilting coefficient was $6.20 \pm 0.60 \%$. At the early stage of vegetation construction, natural precipitation was enough to ensure the normal growth of vegetation as long as the soil moisture content was higher than $2.45 \%$ of the wilting coefficient and that the vegetation entered the non-irrigation stage.

\section{Spatial variation features of SMC in different slope positions}

Of the three slope surfaces, the ASMC at the non-irrigation stage was the highest in the first slope surface, followed by the second and third slope surfaces, successively. On the whole, the SMC increased from the top to the bottom of the slope surface (Feng et al., 2013; Legates et al., 2011). The SMC of the three slope surfaces at the irrigation stage were different from the above. The reason was probably that the variability of environmental factors in the three slope surfaces of the stepped slope led to spatial differentiation features of soil moisture content. A correlation analysis was performed between the SMC and environmental factors (Table 5). The results showed that soil hardness and terrain factor had a larger impact on soil moisture in the stepped slope. As to the soil hardness, it was highest in the upper position of the second slope surface $\left(3.14 \mathrm{~kg} \cdot \mathrm{cm}^{-2}\right)$, followed by the middle $\left(4.46 \mathrm{~kg} \cdot \mathrm{cm}^{-2}\right)$ and lower $\left(4.61 \mathrm{~kg} \cdot \mathrm{cm}^{-2}\right)$ positions successively. However, the variation pattern was different for the other two slope surfaces. The average overall soil hardness was the highest in the third slope surface $\left(5.3 \mathrm{~kg} \cdot \mathrm{cm}^{-2}\right)$, followed by the second $\left(4.1 \mathrm{~kg} \cdot \mathrm{cm}^{-2}\right)$ and first $\left(2.6 \mathrm{~kg} \cdot \mathrm{cm}^{-2}\right)$ slope surfaces successively. The lower the soil hardness, the smaller the negative effect on the SMC was. As to the influence of terrain factor, the infiltration-excess surface runoff flowed from the third, then to the second and finally to the first slope surface. In relevant to the slope gradient, it was the highest in the first slope surface, followed by the second and third slope surfaces, successively. The larger the slope gradient, the more likely the runoff formation will be, thus leading to soil moisture loss. Therefore, under the joint influence of soil hardness and terrain factor, SMC of the stepped slope showed the above features of spatial variation.

Most studies would believe that soil hardness, slope position and slope gradient correlated negatively with SMC, while vegetation cover correlated positively with SMC (Ali et al., 2010; Cantón et al., 2004; Ishaq et al., 2001; Yang et al., 2015). In this study, we found that both the soil hardness and slope positive correlated negatively with soil 
moisture content, which agreed with the previous researches (Ali et al., 2010; Cantón et al., 2004; Ishaq et al., 2001; Yang et al., 2015). However, the findings that the SMC correlated positively with slope gradient and negatively with vegetation cover were consistent with the previous researches (Ali et al., 2010; Cantón et al., 2004; Ishaq et al., 2001; Yang et al., 2015). This was because soil hardness and slope position had a greater impact on SMC. Moreover, the test was conducted at the initial stage of vegetation reconstruction, where the root system of the vegetation was not fully developed. For this reason, the slope gradient and vegetation cover had little impact on SMC.

\section{Influence of environmental factors on the stability of SMC in the stepped slope}

Many studies have indicated that the main factors affecting spatial variation of SMC in slopes are soil properties (Fitzjohn et al., 1998; Zhang and Berndtsson, 1988), terrain (Crave and Gascuel-Odoux, 2015; Gómez-Plaza et al., 2001) and vegetation (Bromley et al., 1997; Rodriguez-Iturbe et al., 1999). But given the interaction between these factors and multiplicity of the effect of these factors on SMC, we can hardly determine their relative importance (Grayson et al., 1999). It is widely recognized that soil properties are important affecting factors of spatial distribution of soil moisture. For example, Martinez et al. (2010) opined that the effect of soil properties on spatial differentiation of SMC was greater than that of the terrain factor. However, the effect of terrain factor on spatial distribution of soil moisture was indescribable. Schneider et al. (2011) proposed that soil properties had greater impact on soil moisture, while the influence of vegetation on soil moisture was smaller. Famiglietti et al. (1998) suggested that under humid conditions, soil moisture content variability received the greatest impact from soil properties. While under dry condition, SMC variability was controlled jointly by terrain and soil properties. There are also contending opinions. For example, Tromp-van Meerveld and Mcdonnell (2006) showed that vegetation exerted a greater impact on the spatial distribution of soil moisture content than local terrain. Gwak and Kim (2017) and Kim (2012) opined that terrain was an important affecting factor of spatial distribution of SMC. The soil hardness had significant impact on the spatial variation of SMC. This explained why the SMC was still the smallest even when the gradient of the third slope surface was $25^{\circ}$. This agreed with the findings by Martinez et al. (2010) and Schneider et al. (2011), but disagreed with Gwak and Kim (2017), Kim (2012), Tromp-van Meerveld and Mcdonnell (2006). Ishaq et al. (2001) and Feng et al. (2013) showed that the correlation between soil hardness and SMC weakened with increasing depth, while the correlation of slope gradient and aspect to SMC was strengthened. Our results were in agreement with those. A correlation analysis was performed between the SMC and environmental factors (Table 5). The results showed that soil hardness and terrain factor had a larger impact on soil moisture in the stepped slope.

\section{Conclusion}

Our results indicated that the soil moisture migration of the three slope surfaces (bottom, middle and top) exhibited a similar pattern under different methods and significant of sprinkler irrigation. That is, at the non-irrigation stage and the stage of irrigation once every two days, the SMC increased with increasing depth. Whereas, at the stage of irrigation once daily, the SMC decreased with increasing depth. The SMC 
decreased and the $\mathrm{CV}$ of SMC increased with the decreasing frequency of sprinkler irrigation. However, the ASMC content increased from the top to the bottom of the stepped slope under different frequencies of sprinkler irrigation. The correlation analysis among the four environmental factors, namely, slope position and gradient, soil hardness and vegetation cover showed positive and negative relationships. The slope position, slope hardness and vegetation cover correlated negatively with the SMC ( $\mathrm{P}<0.01)$. On the other hand, the slope gradient correlated positively with the SMC $(\mathrm{P}<0.05)$. In order to ensure better vegetation growth in the stepped slope under the water conservation context, the frequency and amount of sprinkler irrigation should be adjusted according to the growth status of vegetation. Moreover, reasonable tillage measures such as ploughing should be adopted to reduce soil hardness, increase SMC and promote fast vegetation restoration of the slopes.

The duration of the study is short, so it is difficult to assess and eliminate the impact of soil disturbance caused by infrastructure construction, and the spatial variation of SMC in different slope direction, number of steps and slope gradient needs further study.

Acknowledgement. This study was funded by Open Foundation of Northwest Institute of EcoEnvironment and Resources, Chinese Academy of Sciences (KLDD-2017-004); 2017 Lanzhou Talent Innovation and Startup Project (2017-RC-26).

\section{REFERENCES}

[1] Ali, G. A., Roy, A. G., Legendre, P. (2010): Spatial relationships between soil moisture patterns and topographic variables at multiple scales in a humid temperate forested catchment. - Water Resources Research 46(10): 2290-2296.

[2] Bromley, J., Brouwer, J., Barker, A. P., et al. (1997): The role of surface water redistribution in an area of patterned vegetation in a semi-arid environment, south-west Niger. - Journal of Hydrology 198(1-4): 1-29.

[3] Cantón, Y., Solé-Benet, A., Domingo, F. (2004): Temporal and spatial patterns of soil moisture in semiarid badlands of SE Spain. - Journal of Hydrology 285(1): 199-214.

[4] Choi, M., Jacobs, J. M. (2007): Soil moisture variability of root zone profiles within SMEX02 remote sensin footprints. - Advances in Water Resources 30(4): 883-896.

[5] Cohen-Fernández, A. C., Naeth, M. A. (2013): Erosion control blankets, organic amendments and site variability influenced the initial plant community at a limestone quarry in the Canadian Rocky Mountains. - Biogeosciences 10(7): 5243-5253.

[6] Crave, A., Gascuel-Odoux, C. (2015): The influence of topography on time and space distribution of soil surface water content. - Hydrological Processes 11(2): 203-210.

[7] Engelbrecht, B. M. J., Comita, L. S., Condit, R., et al. (2007): Drought sensitivity shapes species distribution patterns in tropical forests. - Nature 447(7140): 80-82.

[8] Famiglietti, J. S., Rudnicki, J. W., Rodell, M. (1998): Variability in surface moisture content along a hillslope transect: Rattlesnake Hill, Texas. - Journal of Hydrology 210(1): 259-281.

[9] Feng, Q., Zhao, W., Qiu, Y., et al. (2013): Spatial heterogeneity of soil moisture and the scale variability of its influencing factors: a case study in the loess plateau of China. Water 5(3): 1226-1242.

[10] Fitzjohn, C., Ternan, J. L., Williams, A. G. (1998): Soil moisture variability in a semiarid gully catchment: implications for runoff and erosion control. - Catena 32(1): 55-70. 
[11] Gómez-Plaza, A., Martínez-Mena, M., Albaladejo, J., et al. (2001): Factors regulating spatial distribution of soil water content in small semiarid catchments. - Journal of Hydrology 253(1): 211-226.

[12] Grayson, R. B., Blöschl, G., Willgoose, G. R., et al. (1999): Observed spatial organization of soil moisture and its relation to terrain indices. - Water Resources Research 35(3): 797-810.

[13] Gwak, Y., Kim, S. (2017): Factors affecting soil moisture spatial variability for a humid forest hillslope. - Hydrol. Process 31(2): 431-445.

[14] Ishaq, M., Hassan, A., Saeed, M., et al. (2001): Subsoil compaction effects on crops in Punjab, Pakistan: I. Soil physical properties and crop yield. - Soil \& Tillage Research 60(3): 153-161.

[15] Jia, Y. H., Shao, M. A., Jia, X. X. (2013): Spatial pattern of soil moisture and its temporal stability within profiles on a loessial slope in northwestern China. - Journal of Hydrology 495(15): 150-161.

[16] Kim, S. (2012): Characterization of annual soil moisture response pattern on a hillslope in Bongsunsa Watershed, South Korea. - Journal of Hydrology 448-449(15): 100-111.

[17] Legates, D. R., Mahmood, R., Levia, D. F., et al. (2011): Soil moisture: a central and unifying theme in physical geography. - Progress in Physical Geography: Earth and Environment 35(1): 65-86.

[18] Liu, L., Sun, H., Zhang, J., et al. (2019): Effect of several engineering measures on vegetation coverage on steep slope in the Loess region. - Arid Zone Research 36(4): 1041-1048.

[19] Martinez, C., Hancock, G. R., Kalma, J. D., et al. (2010): Spatio-temporal distribution of near-surface and root zone soil moisture at the catchment scale. - Hydrological Processes 22(14): 2699-2714.

[20] Miyazaki, T., Hasegawa, S., Kasubuchi, T. (1993): Water flow in soils. - Soil Science 157(4).

[21] Morgan, R. P. C. (1980): Implications. - In: Kirby, M. J., Morgan, R. P. C. (eds.) Soil Erosion. Wiley, New York, pp. 253-301.

[22] Rodriguez-Iturbe, I., D’Odorico, P., Porporato, A., et al. (1999): On the spatial and temporal links between vegetation, climate, and soil moisture. - Water Resources Research 35(12): 3709-3722.

[23] Schneider, K., Leopold, U., Gerschlauer, F., et al. (2011): Spatial and temporal variation of soil moisture in dependence of multiple environmental parameters in semi-arid grasslands. - Plant and Soil 340(1): 73-88.

[24] Seneviratne, S. I., Davin, E., Hirschi, M., et al. (2011): Soil moisture-ecosystem-climate interactions in a changing climate: - AGU Fall Meeting, 5-9 December, San Francisco, CA.

[25] Sharma, L. K., Umrao, R. K., Singh, R., et al. (2017): Stability investigation of hill cut soil slopes along National highway 222 at Malshej Ghat, Maharashtra. - Journal of the Geological Society of India 89(2): 165-174.

[26] Soane, B. D., Blackwell, P. S., Dickson, J. W., et al. (1980): Compaction by agricultural vehicles: a review I. Soil and wheel characteristics. - Soil \& Tillage Research 1(3): 207237.

[27] Stokes, A., Norris, J. E., Greenwood, J. R. (2008): Introduction to Ecotechnological Solutions. - Springer, Dordrecht.

[28] Tromp-van Meerveld, H. J., Mcdonnell, J. J. (2006): On the interrelations between topography, soil depth, soil moisture, transpiration rates and species distribution at the hillslope scale. - Advances in Water Resources 29(2): 293-310.

[29] Vivoni, E. R., Rinehart, A. J., Méndez-Barroso, L. A., et al. (2010): Vegetation controls on soil moisture distribution in the Valles Caldera, New Mexico, during the North American monsoon. - Ecohydrology 1(3): 225-238. 
[30] Wu, Q., Yang, W. (1998): Vegetation Construction and Sustainable Development in the Loess Plateau. - Science Press, Beijing.

[31] Yang, L., Chen, L., Wei, W. (2015): Effects of vegetation restoration on the spatial distribution of soil moisture at the hillslope scale in semi-arid regions. - Catena 124(1): 138-146.

[32] Yang, W., Shao, M. (2000): Study on Soil Moisture in Loess Plateau. - Science Press, Beijing.

[33] Yang, Y., Yang, J., Zhao, T., et al. (2016): Ecological restoration of highway slope by covering with straw-mat and seeding with grass-legume mixture. - Ecological Engineering 90: 68-76.

[34] Yao, X., Fu, B., Lu, Y. (2012): Spatial patterns of soil moisture at transect scale in the Loess Plateau of China. - Acta Ecologica Sinica 32(16): 4961-4968.

[35] Zhang, T., Berndtsson, R. (1988): Temporal patterns and spatial scale of soil water variability in a small humid catchment. - Journal of Hydrology 104(1): 111-128. 